\title{
DETECTION OF Mycobacterium leprae DNA FOR 36kDa PROTEIN IN URINE FROM LEPROSY PATIENTS: A PRELIMINARY REPORT
}

\author{
Om PARKASH, Hari Bhan SINGH, Subha RAI(1), Archna PANDEY(1), Vishwa Mohan KATOCH \& Bhawneshwar Kumar GIRDHAR
}

\begin{abstract}
SUMMARY
We have searched for Mycobacterium leprae DNA for 36kDa protein in urine using a M. leprae specific PCR technique. A limited number of 16 patients (of which 11 belonged to lepromatous leprosy and five to tuberculoid leprosy) and eight healthy individuals were included for the present study. The number of urine samples positive by PCR were 36.4\% (4/11) in lepromatous patients and $40 \%$ (2/5) in tuberculoid patients. None of the samples from healthy individuals was positive. To our knowledge, the results indicate, for the first time, the presence of $M$. leprae DNA in urine from leprosy patients. Another important finding obtained out of the study is that amongst treated patients $66.6 \%$ (4/6) were positive whereas amongst untreated only $20 \%(2 / 10)$ were positive. From the present indicative data it appears that treatment improves the PCR results with urine as a sample. Thus, the approach could prove to be useful for monitoring the treatment response of individual patients and needs to be further evaluated with a large number of patients.
\end{abstract}

KEYWORDS: Urine; Leprosy; Mycobacterium leprae; DNA; PCR; Diagnosis

Leprosy is a chronic infectious disease caused by Mycobacterium leprae. The disease manifests in various forms resulting in a spectrum ${ }^{8}$. At one pole of the spectrum lies tuberculoid leprosy (TT) while at the other one lies lepromatous leprosy (LL). Between these two polar types various borderline forms (i.e. BT-borderline tuberculoid, BB-midborderline, BL-borderline lepromatous leprosy) have been described. In tuberculoid leprosy there is a localized skin and/or nerve lesion(s), with a low bacterial load and strong cell mediated immunity. In contrast, lepromatous leprosy has generalized lesions with a high bacterial load and strong humoral immunity. Immunological examination of urine from leprosy patients has shown that samples from a proportion of leprosy patients are positive for antigens and antibodies in the urine $e^{4,5,6}$. Though, there are reports documenting mycobacterial DNA in urine from patients suffering from infectious diseases ${ }^{7,10}$, to our knowledge, there is hardly any information, demonstrating $M$. leprae DNA in urine from leprosy patients. With skin biopsies from leprosy patients a specific PCR for detection of DNA for $36 \mathrm{kDa}$ antigen has already been published ${ }^{1,2}$ in the literature. In this pilot study, we have made an attempt to detect $M$. leprae DNA for $36 \mathrm{kDa}$ protein in urine from leprosy patients.

Sixteen active leprosy patients (who attended the out patient department at Central JALMA Institute for leprosy, Agra) and eight healthy individuals were included for the study. Patients were diagnosed using clinical criteria and classified according to RIDLEY \& JOPLING ${ }^{8}$ scale. None of the patients had any symptom indicating the defective renal function. Of the 16 patients, six were on anti leprosy treatment. Various relevant clinical features have been depicted in Table 1.

After obtaining the informed consent from all the individuals, they were requested to produce urine. Ten $\mathrm{ml}$ of the urine sample was centrifuged at $12,074 \mathrm{~g}$ for $20 \mathrm{~min}$ at $4{ }^{\circ} \mathrm{C}$. The supernatant was discarded and the pellet was suspended in $500 \mu \mathrm{l}$ of $10 \mathrm{mM}$ Tris- $\mathrm{HCl}$ supplemented with $1 \mathrm{mM}$ ethylene diamine tetra-acetic acid (TE, $\mathrm{pH}$ 8.0). If needed, samples were stored at $-20{ }^{\circ} \mathrm{C}$ till they were used.

The suspension of urine sediment $(430 \mu \mathrm{l})$ in TE was boiled for 10 minutes. It was then followed by sudden cooling and treatment with 50 $\mu l$ lysozyme $(20 \mathrm{mg} / \mathrm{ml})$ for two hrs at $37^{\circ} \mathrm{C}$. Next, $5 \mu$ l of proteinase-K $(10 \mathrm{mg} / \mathrm{ml})$ and $56 \mu \mathrm{l}$ of $10 \%$ sodium dodecyl sulphate (SDS) were mixed and incubated for one hour at $65^{\circ} \mathrm{C}$. Then, $80 \mu \mathrm{l}$ of $5 \mathrm{M}$ sodium chloride $(\mathrm{NaCl})$ and $64 \mu \mathrm{l}$ cetyl tri-methylammonium bromide (CTAB; 20mg/ $\mathrm{ml}$ ) were added to the mixture and incubated for $30 \mathrm{~min}$ at $65{ }^{\circ} \mathrm{C}$. The suspension thus obtained was treated with equal volume of chloroformiso-alcohol (1:24) solution, vortexed and centrifuged at 12,074 $\mathrm{g}$ for five minutes. Supernatant was mixed with iso-propanol ( 0.6 times by volume) in a separate tube. The contents of the tube were kept at $-20^{\circ} \mathrm{C}$ overnight. Later on, the tube was centrifuged at $12,074 \mathrm{~g}$ for $15 \mathrm{~min}$, sediment in the tube was mixed after discarding the supernatant. Seventy percent ethanol $(150 \mu \mathrm{l})$ was then added to the mixture and the tube was centrifuged for 7 minutes at 12,074 g. Finally, after drying the ethanol 


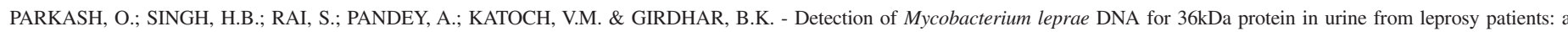
preliminary report. Rev. Inst. Med. trop. S. Paulo, 46(5):275-277, 2004.

Table 1

Details of patients analyzed by PCR

\begin{tabular}{cccccc}
\hline Patient & $\begin{array}{c}\text { Disease duration } \\
\text { (Months) }\end{array}$ & $\begin{array}{c}\text { Treatment duration } \\
\text { (Months) }\end{array}$ & $\begin{array}{c}\text { Bacterial Index } \\
(\mathrm{BI})\end{array}$ & Type of disease & PCR result \\
\hline 1 & 6 & Untreated & 0 & BT & + \\
2 & 12 & Untreated & 0 & BT & - \\
3 & 1.5 & Untreated & 3 & LL & - \\
4 & 36 & Untreated & 5 & LL & + \\
5 & 24 & 5 & 4 & BL & - \\
6 & 24 & Untreated & 3 & LL & - \\
7 & 72 & 1.5 & 5 & LL & + \\
8 & 3 & 3 & 4 & BL & - \\
9 & 18 & 4 & 3 & LL & - \\
10 & 12 & 2 & 3.5 & LL & + \\
11 & 36 & 4 & BT & BL & - \\
12 & 18 & Untreated & 0 & BT & - \\
13 & 6 & 6 & 0 & BT & - \\
14 & 36 & Untreated & 0 & 0 & \\
15 & 12 & Untreated & Untreated & & \\
16 & 3 & & & & \\
\hline
\end{tabular}

from the sample, $20 \mu \mathrm{l}$ of TE buffer was added to the contents in the tube and preserved at $-20{ }^{\circ} \mathrm{C}$ till use. While performing this procedure all precautions were taken to prevent cross contamination.

DNA extracted from samples were subjected to PCR following the methods, with slight modification, described previously by HARTSKEERL et $a l .{ }^{2}$ and DE WIT et al. ${ }^{1}$ where the target for amplification was $530 \mathrm{bp}$ sequence on the gene encoding the $36 \mathrm{kDa}$ antigen. The method included both, positive and negative controls. The denaturation, annealing and extension steps were carried out at $94{ }^{\circ} \mathrm{C}$ for two minutes, at $60{ }^{\circ} \mathrm{C}$ for two minutes and at $72{ }^{\circ} \mathrm{C}$ for three minutes respectively. The amplicon obtained out of this procedure was analyzed by agarose gel electorophoresis incorporated with $0.05 \mu \mathrm{l} / \mathrm{ml}$ of ethidium bromide $(0.5 \mathrm{mg} / \mathrm{ml})$. On completion of the run the separated PCR products were transferred to positively charged nylon membrane. The transferred products were then probed with a digoxigenin labeled 530 bp fragment specific for DNA encoding for $36 \mathrm{kDa}$ antigen. All steps including labeling of the probe, hybridization and detection employing anti-digoxigenin antibody conjugated with alkaline phosphatase using the substrate 5-bromo-4-chloro-3-indolyl phosphate and nitroblue tetrazolium salt were performed as described by the manufacturer (Roche Diagnostics, Mannheim, Germany). A specimen was considered positive when a 530 bp band was revealed by both agarose gel electrophoresis and subsequent hybridization.

The overall positivity rate (Table 2 ) with samples from leprosy patients was $37.5 \%(6 / 16)$. None of the healthy controls was detected to be positive. The group-wise positivity was $36.4 \%$ (4/11) with samples from lepromatous patients and 40 percent (2/5) with samples from borderline tuberculoid patients. In BT group of patients the cell mediated immune response is known to be comparatively better than LL/BL type of patients ${ }^{8}$. Probably, there may be continuous damage (at slow rate) of M. leprae in BT patients resulting in more DNA release in the blood and thereby more excretion in the urine leading to better positivity, though
Table 2

Performance of PCR for detection of $M$. leprae DNA in urine

\begin{tabular}{lccc}
\hline Leprosy status & Positive & Negative & Positivity $(\%)$ \\
\hline Lepromatous & $4 / 11$ & $7 / 11$ & 36.4 \\
Tuberculoid & $2 / 5$ & $3 / 5$ & 40 \\
All & $6 / 16$ & $10 / 16$ & 37.5 \\
Healthy & $0 / 8$ & $8 / 8$ & 0 \\
Untreated & $2 / 10$ & $8 / 10$ & 20 \\
Treated & $4 / 6$ & $2 / 6$ & 66.7 \\
\hline
\end{tabular}

insignificant, when compared to BL/LL patients. On the other hand, with LL/BL patients the situation is reverse. Further, no association between PCR status and clinical features including bacterial indices were found. To conclude, detecting urinary DNA for $36 \mathrm{kDa}$ protein does not appear to be a helpful tool for diagnosis of M. leprae infection.

In leprosy, efforts have been made in the past to demonstrate $M$. leprae DNA in a variety of clinical samples such as skin, lymph, blood, nasal secretions, hair bulbs and fresh biopsy ${ }^{9}$. To our knowledge, present is the first report regarding demonstration of $M$. leprae DNA in urine from leprosy patients. The appearance of $M$. leprae DNA in urine from leprosy patients does not seem to be surprising as prevalence of antigens and antibodies in urine from leprosy patients is already $\operatorname{known}^{4,5,6}$. However, mechanism of getting DNA and even antigen and antibody is not known as yet.

One interesting observation obtained out of the present study is that amongst treated patients $66.7 \%$ (4/6) were positive whereas only $20 \%$ $(2 / 10)$ samples were positive from untreated group. Surprisingly, all the patients having taken three or more than three months treatment were positive by PCR. This indicative data points out that probably treatment 
affects the PCR results by enhancing the release of DNA in the urine. It is known that due to treatment $M$. leprae is damaged and then eliminated from the host tissues ${ }^{3}$. During this process, various bacterial components including bacterial DNA might be released in the host tissues and DNA thus released might get way in the urine. Hence, detecting DNA in urine appears to be worthwhile to explore further on large number of samples for establishing its utility in monitoring the response to chemotherapy in leprosy patients.

\section{RESUMO}

\section{Detecção do DNA do Mycobacterium leprae para proteína 36 kDa na urina de pacientes com hanseníase: relato preliminar}

Pesquisamos o DNA do Mycobacterium leprae para proteína 36 kDa na urina usando a técnica do PCR específica para $M$. leprae. Um número limitado de 16 pacientes (dos quais 11 tinham hanseníase multibacilar e cinco hanseníase paucibacilar) e oito indivíduos saudáveis foram incluídos neste estudo. O número de amostras de urina positivas pelo PCR foi de 36,4\% (4/11) em pacientes com hanseníase multibacilar e $40 \%$ (2/5) em pacientes com hanseníase paucibacilar. Nenhuma das amostras de indivíduos saudáveis foi positiva. Até onde chega o nosso conhecimento, os resultados indicam, pela primeira vez, a presença de DNA do M. leprae na urina de pacientes com hanseníase. Outro fato importante obtido através do exame é que entre os pacientes tratados $66.6 \%$ (4/6) eram positivos enquanto entre os não tratados somente $20 \%$ $(2 / 10)$ foram positivos. Pelos presentes dados indicativos parece que o tratamento melhora os resultados do PCR em amostra de urina. Assim, o acesso a estes dados prova ser útil no monitoramento da resposta ao tratamento de pacientes individuais e precisa ser melhor avaliado com um grande número de pacientes.

\section{ACKNOWLEDGEMENTS}

The authors extend thanks to Mr. P.N. Sharma, M. Alam, Mrs. Suman Lata Aggarwal, for their respective technical assistance/co-operation during the study. Some of the materials used for the study were financed by Lepra, UK.

\section{REFERENCES}

1. DE WIT, M.Y.L.; FABER, W.R.; KRIEG, S.R. et al. - Application of a polymerase chain reaction for the detection of Mycobacterium leprae in skin tissues. J. clin. Microbiol., 29: 906-910, 1991.

2. HARTSKEERL, R.A.; DE WIT, M.Y.L. \& KLATSER, P.R. - Polymerase chain reaction for the detection of Mycobacterium leprae. J. gen. Microbiol., 135: 2357- 2364, 1989.

3. JAMIL, S.; KEER, J.T.; LUCAS, S.B. et al. - Use of polymerase chain reaction to assess efficacy of leprosy chemotherapy. Lancet., 342: 264-268, 1993.

4. OlCEN, P.; HARBOE, M.; WARNDORFF, T. \& BELEHU, A. - Antigens of Mycobacterium leprae and anti-M. leprae antibodies in the urine of leprosy patients. Leprosy Rev., 54: 203-216, 1983.

5. PARKASH, O. - Progress towards development of immunoassays for detection of Mycobacterium leprae infection, employing 35kDa antigen: an update. Leprosy Rev., 73: 9-19, 2002.

6. PATIL, S.A.; KATOCH, K. \& SENGUPTA, U. - Detection of Mycobacterium leprae antigens in urine of leprosy patients by monoclonal-antibody-based sandwich immunoradiometric assay and avidin-biotin based immunoblotting. Serodiag. Immunother. infect. Dis., 1: 17-22, 1998.

7. PORTILLO-GOMEZ, L.; MORRIS, S.L. \& PANDURO, A. - Rapid and efficient detection of extra-pulmonary Mycobacterium tuberculosis by PCR analysis. Int. J. Tuberc. Lung. Dis., 4: 361-370, 2000.

8. RIDLEY, D.S. \& JOPLING, W.H. - Classification of leprosy according to immunity. A five group system. Int. J. Leprosy other mycobact. Dis., 34: 255-273, 1966.

9. SANTOS, A.R.; DEGRAVE, W.M. \&. SUFFYS, P.N. - Use of polymerase chain reaction (PCR) in leprosy research. Indian J. Leprosy, 71: 101-110, 1999.

10. SECHI, L.A.; PINNA, M.P.; SANNA, A. et al. - Detection of Mycobacterium tuberculosis by PCR analysis of urine and other clinical samples from AIDS and non-HIV-infected patients. Molec. Cell Probes, 11: 281-285, 1997.

Received: 15 July 2004

Accepted: 15 September 2004 